\title{
Crash Cesarean Delivery
}

National Cancer Institute

\section{Source}

National Cancer Institute. Crash Cesarean Delivery. NCI Thesaurus. Code C92762.

An emerg ency cesarean section that is carried out urg ently in cases of fetal distress or severe maternal complication that is life threatening to either or both of them. 